\title{
Compliance With International Financial Reporting Standards and Value Relevance of Accounting Information in South Africa
}

\author{
Unity Maqeda Putsai ${ }^{1} \&$ Msizi Mkhize ${ }^{1}$ \\ ${ }^{1}$ School of Accounting, Economics and finance, Westville campus, University of KwaZulu Natal, KwaZulu-Natal, \\ South Africa \\ Correspondence: Unity Maqeda Putsai, School of Accounting, Economics and finance, Westville campus, University \\ of KwaZulu Natal, KwaZulu-Natal, South Africa.
}

Received: January 20, 2021

Accepted: March 4, 2021

Online Published: June 21, 2021

doi:10.5430/ijfr.v12n4p277

URL: https://doi.org/10.5430/ijfr.v12n4p277

\begin{abstract}
The objective of the study is to investigate the relationship between the International Financial Reporting Standard (IFRS 1) and the value relevance (VR) of accounting information. In this study forty-six companies listed on the Johannesburg Stock Exchange during the period 1993 to 2017. Panel data is used to compare the period before and after IFRS. The companies in the sample are composed of the following sectors; mining, manufacturing, banks and investment companies, real estate, general industry, retailers, construction and material, chemical and software, and computers. Based on the yearly financial reports published by public companies in South Africa, the study employed the Cookes (1992) Unweighted Disclosure Index to measure the level of compliance in South Africa. Fifty-six disclosure elements from IFRS 1 were utilized to measure the compliance level. Thereafter Ohlson (1995) Model is used with dummy variables to compare the pre-and post-IFRS period. First, the study reflected that most of the South African companies exhibit higher compliance rates ranging from 87 to 93.417 which is impressive. On the other hand, 4 companies recorded Medium level compliance that is between $60 \%$ to $79 \%$ compliance level. The findings further revealed that there is a significant positive association between compliance with IFRS 1 and the value relevance of accounting information.
\end{abstract}

Keywords: compliance, IFRS, value relevance, Ohlson Model, mandatory disclosure, GAAP

\section{Introduction}

In 2004, the Republic of South Africa accomplished the convergence and the transition to IFRS commenced in early 2005, thus eliminating all the differences between the South African GAAP and the IFRS (International GAAP, 2012). Furthermore, as of the 1st of January 2005, all the JSE compelled all listed firms to prepare their financial reports following the IFRS. All the public firms that were not yet ready to publish their reports under IFRS started the transition by implementing IFRS 1. International GAAP (2012), revealed that non-listed firms in the Republic of South Africa were flexible to prepare their financial reports either using IFRS or SA GAAP. According to Quezzani and Alami (2014), South Africa adopted the 'implementation process' as a method of implementation of IFRS.

According to the IFRS Foundation (2016), the transition to IFRS by all the companies in the world enhances the comparability as well as transparency of financial reports thereby minimizing financial statement compilation expenses. Also, when IFRS is applied rigorously and consistently all the capital market participants would benefit from higher quality information for informed decisions. South Africa is facing some challenges of capital thereby causing most of the public companies to liquidate. Producing value relevant accounting information can help the country to address the issues of capital.

\subsection{Research Problem}

Public companies are the main players in the economic growth but in 2011 the mining sector recorded a loss of five percent and the agricultural sector had a loss of nine percent (The Report South Africa, 2012). The IMF Country Report 15/57 (2015) stated that there is a lack of explicit requirements for the public firms to check on their capital adequacy every day. Also, the issues of capital adequacy are causing public companies to liquidate. The study would be of paramount importance because it is going to address the problems of liquidation, and non-compliance. 


\section{Literature Review}

\subsection{The Motivation of the Study}

Lin (2012) highlighted that in developing and less-developed countries (DLDC) the major problem that they face is the incompetency of the ruling government which is mostly caused by corruption within the members of the state, under-performing of law enforcement departments. It is not specified if these nations are benefitting from the transition to IFRS (Lin, 2014). South Africa is one of the developing nations; therefore the current study will provide fresh evidence about the relationship between compliance with IFRS 1 and the value relevance of the accounting system of public companies. The law enforcement, as well as the government of South Africa, might be inefficient but the study reveals management's incentives for producing value-relevant financial reports not only enhancing the degree of compliance with IFRS but also assisting companies to benefit from adopting the common standards.

An investigation on the relationship between compliance and value relevance of accounting information helps South Africa produce high-quality financial information that can attract investors to improve economic growth.

\subsection{Compliance With IFRS}

Vasek (2015) investigated whether IFRS could be considered as global accounting standards basing on the world-wide jurisdiction profile. The investigation was based on the outcome of IASB's survey that was completed in November 2014. In this study, the following three aspects were considered; the number of firms that transitioned to IFRS, the number of firms that published the IFRS financial reports as well as the market capitalization of the firms. The outcome of the study revealed that the overall number of listed companies in the world, which use IFRS represents a small fraction which is not correct to consider IFRS as the global standard. On the other side, if the firms are expressed by their size in terms of the financial positions then IFRS can be considered as the global standard because public companies are known as the key drivers of the national economy.

Cascino and Gassen (2015) scrutinized the effect of IFRS adoption focusing on the comparability of financial reports. To achieve the objectives in this research the authors gathered data on IFRS compliance from the two nations namely Germany and Italy. Thereafter the level of compliance determinants was then considered to provide the full explanation on the comparability of financial reports. The outcome showed that in a nutshell, the comparability effect on mandatory adoption of the common standards is marginal. Determinants like company, region, and country-level incentives have a positive effect on molding the IFRS. Similar compliance determinants were employed to provide a full explanation of the variance in the comparability effect of IFRS financial reports. The outcome reflected that firms that receive some incentives on IFRS compliance have greatly improved comparability.

Using a sample of all the public firms in Turkey, Kilic et al (2016) have examined the factors that negatively affect the level of compliance. A comprehensive questionnaire was distributed to both listed and unlisted companies in Turkey. Also, employee training, foreign ownership as well as firm size were vital determinants of the level of IFRS compliance. The outcome revealed that the level of compliance with IFRS in Turkey was very low.

In Brazil, Santos2 at. al (2018) assessed the relationship that exists between analysts' earnings forecasts errors and the level of IFRS compliance of public firms. Using a sample of one-hundred and twenty-three firms, the authors used the notes to the financial reports to assess the level of compliance with the IFRS. Twenty-five standards of choice were utilized to measure the compliance level. The results mirrored that the level of compliance with the common standards was very low as compared to other Continental European companies. The authors identified a negative relationship between the company's compliance level and the analysts' earnings forecast error.

Muller (2014) investigated the effect of IFRS on ninety-eight consolidated companies listed on the three largest European Stock Exchange. Using economic regression models, five-hundred and eight-eight company year observations were analyzed to compare the level of compliance between pre and post IFRS. The findings reflected that the adoption of the common standards enhanced the degree of compliance in European countries.

\subsection{Value Relevance (VR) of Financial Information}

In India, Khanna (2014) analyzed the VR of financial reports published by two hundred and forty-one listed companies. The sampled companies consist of both private and public banks. The study examined the effect of nine variables on the market price of a share. A comparison was made between five years before IFRS and five years after IFRS (2005 to 2010). All the variables were regressed through panel least regression. The outcome revealed that the following variables were significant in the non-listed banks; EPS, BVPS, the turnover of the total assets, and the current ratio that is assets: current liabilities. On public sector banks in India, the findings reflected that EPS, BVPS, $\mathrm{ROE}$ as well as the non-performing assets ratio are significant. The author concluded that the value relevance of 
accounting information before the adoption of IFRS was more superior to the period after IFRS. It was also noted that the value relevance of accounting information in non-listed banks was less effective than the public banks. Lastly, the results indicated that the combined value relevance of accounting information declined after the adoption of IFRS.

In Sri Lanka, Yasas and Perera (2019) analyzed the effect of the uniform standards on the value relevance of the quality of accounting information from 2009 to 2015. The sample of the study is comprised of two hundred and ninety-six manufacturing firms listed on the Colombo Stock Exchange (CSE). For the study to become a success, regression models were used for data analyses of pre and post-IFRS. The variables that were analyzed are EPS, BVPS, leverage, and, the net operating cash flow (NOPC). The outcome of both EPS and BVPS showed an increased mean but the value relevance declined. Leverage, NOCF, BVSP as well as the MVPS reflected an increase on the median but still, a decline in NOCF was noted. The authors concluded that IFRS did not improve the value relevance of accounting information.

In Nigeria again, Nwaobia et al. (2016) analyzed the VR of accounting information of twenty-eight firms listed on the Nigeria stock exchange (NSE). This study concentrated on firms that belong to the consumer goods sector. Data were extracted from the published financial reports of the listed firms. The study employed Modified Ohlson Model to conduct the data analyses. The authors also utilized content analysis for measuring the qualitative figures which are as follows; relevance, understandability of the common standards, comparability of the financial reports, timeliness which is publishing the financial reports of a company during the period that they are required, and also the faithful representation of final accounts. The findings reflected that the adoption of the uniform standards did not change the VR of financial reports. Also, the quality of information did not change after the adoption of uniform standards. Nwaobia et al (2016) concluded that the adoption of the common standards had no significant impact on accounting information that is linked to the value of the company.

In Germany, Zicke and Kiy (2017) assessed the effect of IFRS on the VR of accounting information. Using a sample of four hundred and thirty-six public companies, the study compared pre and post-IFRS regimes from 2005 to 2014. Two-thousand five-hundred and one-year observations were taken into consideration. Several comparisons were done and the outcome revealed that an increase in discretional accruals was not noted but did not affect the income smoothing during the implementation of the uniform standards. Second, the adoption of IFRS did not cause any changes in the earnings of the public firms. There were no changes in the presentation of financial statements meaning the VR of accounting information was the same after the adoption of the common standards.

\subsection{The Association Between Compliance and VR of Accounting Information}

In Hong Kong, Chan et al. (2011) analyzed the relationship between the VR of accounting information and compliance. The study employed a sample of two-hundred and twenty-two disclosure checklist from the various audit committees. The findings showed that the experts from audit committees failed to produce value-relevant information even though they complied with the disclosure requirements.

Okafor et al. (2017) investigated the correlation between the adoption of common standards and the VR of financial information in Nigeria. The study utilized a sample of twelve consumer companies listed on the Nigerian Stock Exchange, the findings reflected that compliance with the IFRS has a positive effect on the value relevance of accounting information. Similar studies were also carried out by Desoky and Mousa (2014); Umoren and Enang (2015); and Uthman and Baki (2014).

In Nigeria, Alade et al. (2017) examined the association between compliance and VR of accounting information in one-hundred and twenty-eight firms listed on the Nigerian stock market. Using a time frame of four years that is from 2012 - 2015, a disclosure checklist with five-hundred and three IFRS disclosure elements was employed to measure compliance. The outcome showed a high compliance level of ninety-one percent. After running the regression on panel data, the findings reflected that there is a positive significant relationship between compliance with IFRS and the VR of accounting information.

Usman and Ndagi (2019) analyzed the relationship between the degree of compliance and the VR of three accounting standards are IFRS 16, IFRS 19, and IFRS 7. The study employed two-hundred and fifty-nine-year observations extracted from the Thomson Reuters database. The authors used an unweighted disclosure index to measure the level of compliance and on the other hand company size, industry type, leverage as well as audit firm were utilized for analyzing the value relevant. Modified Ohlson Model was employed to investigate the value relevance of accounting information. The outcome shows that a high level of compliance with IFRS produces value 
relevant accounting information that is reliable. Also, investors of public firms influence the share price of a company.

In Hong Kong, Chan et al. (2011) analyzed the relationship between the VR of financial information and compliance. The study employed a sample of two-hundred and twenty-two disclosure checklist from the various audit committees. The findings showed that the experts from audit committees failed to produce value-relevant information even though they complied with the disclosure requirements.

In Nigeria, Alade et al. (2017) examined the association between compliance and VR of financial reports in one-hundred and twenty-eight firms listed on the Nigerian stock market. Using a time frame of four years that is from 2012 - 2015, a disclosure checklist with five-hundred and three IFRS disclosure elements was employed to measure compliance. The outcome showed a high compliance level of ninety-one percent. After running the regression on panel data, the findings reflected that there is a positive significant relationship between compliance with IFRS and the value relevance of accounting information.

In Brazil, Souza and Borba (2017) investigated the link between compliance with IFRS and the VR of financial information focusing on the share price as well as the goodwill of business combinations. The study covered the period from 2010-2013 and about two-hundred and two observations from the business combinations registered on Sao Paolo Stock Exchange were analyzed using the disclosure checklist. Financial statements were extracted from the Sao Paulo Stock Exchange as well as the companies' websites. The findings mirrored that the level of compliance in business combinations is positively significantly associated with the value of the share. On the other hand, goodwill does not influence the stock price. The authors also indicated that the average level of compliance was very low therefore an improvement is highly recommended.

Considering the above-stated studies, there are mixed findings on compliance with the common standards and the effect of IFRS on the VR of accounting information. The current study is going to add literature that can clarify the conflicts in the area of compliance and value relevance of financial reports.

\subsection{Previous Studies on the Adoption of IFRS in South Africa}

In South Africa, several types of research were carried out in terms of the adoption of IFRS but none of them focused on compliance with IAS 1 and how it affects the value relevance of accounting information. Swait et al. (2018) investigated the factors that affect the adoption of IFRS 13. Semi-structured interviews were carried out and the findings revealed that the adoption of IFRS 13 was done when the users were not ready and could not understand it very well.

Baigrie and Coetsee (2016) analyzed compliance with financial reports focusing on public agricultural firms. The findings showed that most of the agricultural firms were complying with the disclosure requirements for IAS 41 Agriculture. Zwan and Merwe (2013) evaluated the level of understanding of different stakeholders as far as the IFRS compliant information is concerned. Questionnaires were distributed among different stakeholders like accountants, accountancy students, and others. The outcome reflected that the users of financial reports did not understand the IFRS compliant information under the IASB.

Pududu and Villiers (2016) assessed if the management of public companies in South Africa managed earnings in-order to avoid reporting some losses. The study used secondary data and the findings revealed that there was no concrete evidence on management manipulating the earnings to avoid reporting some losses.

Although the literature concerning the adoption of the common standards is bountiful and is growing at an alarming rate it is the intersection of debate that is found on analyzing the previous studies. The literature on the association between compliance and VR of accounting information stated above showed some mixed findings. Therefore there is a gap that is discovered on the theory which is required by management on measuring the level of disclosure of the common standards and the effect of IFRS on the value relevance of financial reports. The literature revealed that there is a small number of studies on the VR of accounting information in emerging economies as compared to the developed countries (Jianu, 2014). Previous studies also reflected that the JSE market is not analyzed in the area of VR of financial reports. Lastly, literature reflected that accounting information is considered to be value relevant to potential investors and other stakeholders during the decision making on the firm performance.

The study is contributing to the academic literature in the following ways; the findings will bring some new evidence in terms of the association between IFRS 1 and the relevance of financial reports. The current study is crucial because it analysis the level at which the South African accounting regulations have enhanced the relevance of financial information. The above-stated literature reveal some mixed findings regarding the adoption of IFRS, therefore the current study has some implication for standard-setting highlighting the debate on the common 
standards and practices. Lastly, the findings of this study will bring some benefit to South African regulators and management of the companies when deciding on the disclosure policies. Also, the investors are going to benefit from the findings of the study when assessing the public firms' performance in South Africa.

\subsection{Legitimacy Theory}

\subsubsection{Introduction}

Suchman (1995, p. 574) defined legitimacy as the generalizing perceptions or assumptions that the activities of an organization are based on the norms of an organization, values of the stakeholders, and definitions that are acceptable by the community.

For Zehri and Abdelbaki (2013), legitimacy theory is defined as a theoretical stance that can predict firms' behavior about how management is capable of maintaining the perspectives of the key players that are the stakeholders, through publishing the value relevant financial information.

Islam (2017) noted that legitimacy theory is an interface between the company and the social expectations. Also, the goodwill of an organization is not only determined by the market strength but social strength as well. In other words, the companies are not only supposed to market their products and services but also to consider the welfare and expectations of the members of the community. The challenge that is linked to fulfilling societal expectations is that there is always some fluctuations in legitimacy that is caused by a change in taste (Islam, 2017). The author highlighted that when the company is facing some legitimacy threats it becomes so complicated to implement some strategies associated with legitimacy. Also, the company faces some challenges when it is running out of legitimacy strategies. In other words, with or without legitimacy strategies cooperates face the same challenges.

This theory is well known for advocating the organizations maintain the limits as well as norms that are accepted by society. According to Mousa and Hassan (2015), legitimacy theory reveals the extent to which organizations 'social and environmental disclosure is motivated by the structures formulated by the community to be acceptable by the public. Legitimacy theory is considered to be the best in terms of disciplinary background as compared to other theories like management theory, institutional theory as well as stakeholder theory (Mousa and Hassan, 2015). The role of the stakeholders is to maintain legitimacy not to distract the image of the firm. Besides, stakeholders are also responsible for preventing or mitigating the risk of illegitimacy (Mousa and Hassan, 2015). The authors further stated that some control measures are required at every level of legitimacy depending on what the society is expecting in terms of the evolution and changes that are related to the values.

Firms that fulfill the stakeholders' demands have a motivation in complying with legal requirements (Deegan, 2002). For instance, in this study companies which comply with IFRS will maintain their legitimacy. Deegan (2002) further stated that organizations that are attracted to social and environmental disclosures have some chances of responding to negative publicity and also to address the threats that can compromise its legitimacy. Consistent with Mousa and Hassan (2015), corporate environmental disclosure is also considered as the commonly acceptable and cheap vehicle of communication.

Mousa and Hassan (2015) stated that companies that comply with society's expectations accelerate by achieving some economic advantages. These companies retain their customers and easily attract more clients thereby boosting the earnings in the long run. In this case, the chances of liquidating are so slim.

Strategically speaking, organizations maintain legitimacy through management heritage that is linked to the traditional norms of a company, its values, and also modern ethics Archel et al,. (2009). The legitimacy of companies, institutions such as universities, and social survival, in general, is motivated by the lack of legitimacy

According to Burlea-Schiopoiu and Popa (2013), the economic, social, and environment are now forcing the firms and the ruling government to comply and show some respect for the rules, norms, and any other important information. Besides, legitimacy theory is responsible for revealing justifiable factors for disclosing environmental information. Burlea-Schiopoiu and Popa (2013) further stated that there is a global financial crisis as well as the instability of financial markets exert some pressure on companies to revisit their value system thereby emphasizing the significance of legitimacy. Organizations are now forced to intertwine tangible financial resources with invisible legitimacy resources that are crucial for developing the organizational vision (Burlea-Schiopoiu and Popa,2013). The strategic actions that formulate the legitimacy theory are derived from the institutional environments listed by management and accountability requirements. The authors further explained that, in the long run, the problem that is associated with legitimacy rests on the economic condition of a firm and also its financial performance that can create some internal problems accumulating from several dimensional constructs. These problems would be influencing the transitioning from legitimacy to illegitimacy or vice versa. Trust among the shareholders is very 
crucial to maintain legitimacy (Burlea-Schiopoiu and Popa, 2013). Organizations also develop some images that include symbols representing their culture for maintaining legitimacy.

Mahmud (2019) investigated the legitimacy theory and how it is connected to Corporate Social Reporting (CSR). To fulfill the investigation the author gathered literature for evaluation purposes. The findings reflected that a lot of companies are engaged in fake management of their legitimacy as well as fabricating CSR. Mahmud (2019) concluded that legitimacy theory involves assumptions that are not justified even though legitimacy is the driving for publishing the CRS.

\subsubsection{Linking Legitimacy Theory With IFRS}

Zyznarska-Dworczak (2018) analyzed the significance of management accounting when implementing corporate social responsibility (CSR), which is one of the important elements of legitimacy theory. The author highlighted that there are two dimensions of CSR in legitimacy theory which are institutional and strategic legitimacy. Institutional legitimacy focuses on external reporting whereas strategic legitimacy is concentrated on internal accounting. In this study institutional legitimacy is revealed on investigating the effect of IFRS on financial statements during the period 1993 to 2017.

Deegan (2018) stated that legitimacy theory promotes a focus on organizational legitimacy because it gives a full explanation of the manager's voluntary reporting strategies which could be employed by management's decision relating to the disclosure of social as well as environmental performance information. Deegan (2018) further revealed that the legitimacy theory has been used in many accounting studies because it is one of the theories with the highest citations. Legitimacy is considered to be an important tool or resource in the organization, which needs to be maintained for survival (Deegan, 2018). Furthermore, legitimacy theory can easily be manipulated by the decisions made by the management of the organization because it is motivated by profits of which an element of self-interest can arise. Legitimacy can also be compromised if a company does not comply with societal goals (Deegan, 2018). Compliance with IFRS is one of the societal goals which an organization is expected to fulfill. Therefore, if an organization failed to maintain the compliance level, it can end up losing investors.

Legitimacy theory can help to comprehend the organizations' behavior in implementation, formulation, communication of social responsibility policies (Zyznarska-Dworczak, 2018). Also, legitimacy theory helps to fulfill the company's social contract thereby enabling the identification of its objectives.

Legitimacy theory was used in previous accounting studies (Huang et al., 2014; Sari and Prihandini, 2019). In this study, legitimacy theory is appropriate because changing from SA GAAP to IFRS helps to enhance the legitimacy of South Africa in terms of the financial accounting reporting structure.

\subsection{Hypotheses Development on the Link Between Compliance With IFRS and VR of Financial Information}

According to Alali and Foote (2012), compliance with the IFRS has got an effect on the VR of financial reports. Companies need to comply with the IFRS in-order to produce value-relevant financial statements.

Akeem and McMillan (2016) did not support the notion that compliance with IFRS standards improves the VR of financial reports. In this study, VR of accounting information particularly on the returns of a firm was examined and it was concluded that there was no improvement in the value relevance of accounting information after the adoption of IFRS.

The mixed findings in the area of compliance with IFRS and the effect on the VR of financial information led to the formulation of the following hypotheses;

H1: Compliance has a significant impact on the VR of accounting information.

\section{Methodology}

In this study, the total sample is comprised of forty-six listed companies on the Johannesburg Stock Exchange. The study period commences from the year 1993 to 2017. The year 2005 was not included in the sample because it was the year of transitioning to IFRS, a lot of changes took place as well as making mistakes. Data was extracted from the financial reports of the listed firms, Johannesburg Stock Exchange (JSE), and McGregor BFA Library. The following are the categories of the companies involved in a sample; mining, manufacturing, banks and investments, real estates, general retailers, construction and material, chemical, software and, computers. Only companies that adopted the common standards in 2005 were considered in the sample. To fulfill the research objectives, first Cookes (1992) Unweighted disclosure index to measure the level of compliance in South Africa. Fifty-six disclosure elements from IFRS 1 were utilized to measure the compliance level. IFAC 6.3 (2012) stated that IFRS 1 was formulated by the IASB. The draft for this standard was finalized in July 2002. The proposed standard was open for 
comments and amendments until the end of October 2002. In mid-2003, IFRS 1 was issued but with effect from January 2004. The standard was amended by several accounting standards, which should be disclosed in the financial reports if any changes occurred. Thereafter Ohlson (1995) Model is used with dummy variables to compare the pre-and post-IFRS period.

\subsection{Unweighted Disclosure Index / Dichotomous Method}

The unweighted disclosure index was developed by Cooke (1992). According to Cooke (1992), the method regards all the elements as the same. According to Ofoegbu and Odeomelam (2018), the unweighted disclosure index is highly recommended for checking the compliance level with IFRS because it is accepted for measuring and providing the total number of disclosures and it was also used by previous studies [Rajhi (2014); Tran et al. (2019); Mutawaa (2010); Tsebga et al. (2017)] Besides, the method is also easy to understand.

$$
\mathrm{TC}_{\mathrm{J}}=\mathrm{T}=\sum_{\mathrm{i}=1}^{\mathrm{n}} \mathrm{d}_{\mathrm{i}} / \mathrm{M}=\sum_{\mathrm{i}=1}^{\mathrm{m}} \mathrm{d}_{\mathrm{i}}
$$

$\mathrm{TC}_{\mathrm{j}}$ : Overall compliance score for each quoted firm. $(0 \leq \mathrm{TC} \leq 1)$

$\mathrm{T}$ : Overall number of elements disclosed $d_{i}$ by the quoted firm $\mathrm{j}$.

M: Maximal number of applicable disclosure elements for quoted firm $\mathrm{j}$ that could have been disclosed.

In summary

$$
\mathrm{TC}_{\mathrm{J}}=\frac{\mathrm{T}}{\mathrm{M}}
$$

$\mathrm{TC}_{\mathrm{J}}$ which is obtained from the disclosure checklist compiled from IFRS 1 and it is also utilized as the dependant variable in the multivariate regression model.

$\mathrm{TC}_{\mathrm{J}}$ is calculated as follows;

\subsection{Level of Compliance}

According to Sarea et al. (2017), the level of compliance is categorized into three stages. Below is a diagram that explains the three levels of compliance.

\begin{tabular}{ll}
\hline Level of compliance & Percentage \\
\hline High & $80-100$ \\
\hline Medium & $60-79$ \\
\hline Low & $0-59$ \\
\hline
\end{tabular}

Adopted from Sarea et al. (2017)

\subsection{Assessment of the Compliance Level With IFRS 1 Disclosure}

From the methodology, if a company's compliance; the level score is between 80 and 100 percent it is taking as a high compliance level, if it is between 60 and 79 percent it is regarded as a medium compliance level and if it is between 0 and 59 percent it is taking as low compliance level. The compliance level is computed using:

$$
\mathrm{TC}_{\mathrm{J}}=\frac{\mathrm{T}}{\mathrm{M}}
$$

For instance, if Company "A" disclosed fifty elements out of fifty-seven then the dichotomous compliance score is as follows; $(50 / 57) * 100=88 \%$ total compliance. $T C_{J}$ is the dummy variable that is used to capture the influence of IFRS compliance on financial statements of listed companies in South Africa.

\subsection{Explanation of the Dichotomous Method (Cooke, 1992)}

The study employed the Cooke (1992) unweighted disclosure index. The following was used as influential variables; 1 is for every essential element disclosed and 0 is for failing to score an essential element. For other elements that do not apply to other quoted firms are therefore scored as not applicable (n/a). The Unweighted disclosure index Cooke (1996) is known for treating all the elements with equal weights which is a disadvantage when using some standards which involve several elements than others (Rahji, 2014) 
However, in this study, IFRS 1 was used and a total of fifty-six disclosure elements were employed to measure the level of compliance with IFRS in South Africa. There is no consensus in terms of the number of disclosure checklist items. In other studies, the disclosure index was composed of different types of standards, for instance, Rajhi (2014) used one hundred and thirty-one elements from ten standards, Mutawaa (2010) used twelve standards to compile the checklist of one-hundred and one element, Ofuegbu and Odoemelam (2018) utilized one-hundred checklist items compiled from the corporate governance items, directors reports, statement of financial position and various accounting policies.

Agyei-Mensah (2012), employed IFRS 1 as a checklist for measuring the level of compliance. On the selection of the checklist elements the study followed the following procedure;

1. The researcher reviewed previous studies that addressed the adoption and implementation of the common standards and their applicability in South Africa.

2. Relevance to the study focus.

3. For confirmation and validation, all disclosure elements should apply to all the sampled companies. Elements should also be applicable and relevant to the South African environment. In this aspect, the researcher reviewed other publications from SAICA that involved the adoption of IFRS and how they apply to the South African context. The researcher consulted the academic experts and other practicing professionals namely two auditors and one accountant to scrutinize the checklist and scored the financial reports of the forty-six companies for the period 1992-2017. The findings on the compliance score compiled by the author and the other two accounting experts were compared and analyzed. The outcome reflected that there is a substantial agreement between the scores which shows that the research instrument is reliable and there is also minimal subjectivity as far as the scoring process is concerned. In this study, a company is not penalized on the elements that do not apply to the company

\subsection{Compliance and $V R$}

From the literature, it has been confirmed that the adoption of IFRS is different from compliance with disclosure. In that, many firms may adopt IFRS and yet still fail to comply with disclosure. Consequently, the following model will be estimated as well investigating the VR of financial reports and the degree of compliance.

To analyze the potential differences in the valuation coefficients on both the book value of equity as well as the EPS between the two periods, the study introduces dummy variables in the panel data regression. The equation allows the identification of any potential changes (if any) in the summation of the figures produced after the transition to IFRS and also the direction of the change especially the coefficients which are significant in this study.

$$
P_{a t}=B_{0}+B_{1} D V+B_{2} B V_{a t}^{G P \& T C}+B_{3} B V_{a t}^{G P \& T C} * D V+B_{4} E_{a t}^{G P \& T C}+B_{5} E_{a t}^{G P \& T C} * D V+\varepsilon_{a t} .
$$

Table 1. Ohlson (1995) price model with dummy variables

\begin{tabular}{ll}
\hline Symbol & Measurement \\
\hline$P_{a t}$ & Price per share \\
\hline$B_{1}$ to $B_{5}$ & Coefficients \\
\hline DV & $\begin{array}{l}\text { Dummy variable where 1 represent the TC after IFRS period and 0 represents the pre-IFRS } \\
\text { that is SA GAAP }\end{array}$ \\
\hline$B V_{a t}^{G R \& T C}$ & Year-end book value of a share of the company $a$ at time t \\
\hline$E_{a t}^{G R \& C}$ & Earnings per Share of the company $a$ at time t \\
\hline$\varepsilon_{a t}$ & Error term or other value relevant information \\
\hline$B_{0}$ & Constant \\
\hline$a$ & Firm \\
\hline$t$ & Time \\
\hline$G P$ & GAAP period that is Generally Accepted Accounting Principle that is 1993-2004 and \\
\hline TC & To06-2017 \\
\hline
\end{tabular}

Source: Ohlson (1995) Price Model 
This model will offer an analysis of how compliance with IFRS 1 has affected the VR of financial information. Again, it is an avenue to compare the results on the adoption of IFRS with that of compliance level.

\section{Discussion of Findings}

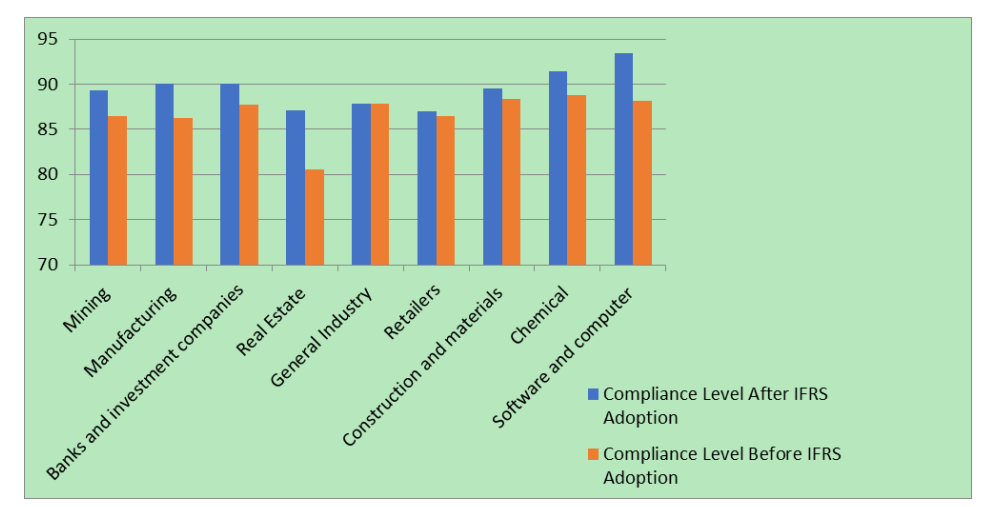

Figure 1. Comparative analysis of Compliance levels before and after IFRS adoption

Source: Author's computation, 2020

Figure 1 shows the picture when the two periods are compared. The result indicates that the compliance level is marginally higher after the adoption of IFRS for all the sectors covered in the survey. The implication is that many of the companies recorded a higher compliance level since the adoption of IFRS in 2005 in South Africa. The change was more visible in the real estate sector with a marginal increase in compliance level of about $7 \%$ followed by the software and computer sector with a rise of about $5 \%$. The change is not all that visible in the general industry as the companies in the sector appear to maintain the same compliance levels before and after the adoption of IFRS.

The percentage distribution of the average compliance level across all the 46 companies and the 9 sectors covered in the study before and after the adoption of IFRS is shown in the figure. The average compliance level for all the sectors combined for before and after the adoption of IFRS is $86.7332 \%$ and 89.52401 for before adoption of IFRS and after adoption IFRS respectively. This is an indication that there is a marginal increase in compliance level of about $2.2 \%$ after IFRS adoption. This change is considered insignificant since the majority of the companies covered in the survey have been recoding above $80 \%$ compliance level even before the adoption of IFRS.

\subsection{Analysis of Compliance With IFRS 1 and VR}

This section of the analysis investigates the role played by compliance in the VR of financial information among South African companies.

\subsection{Panel Unit Root Test for IFRS 1 and Value Relevance}

As usual, before panel estimation an investigation is required on the stationarity of the three additional variables in the model namely; TC, BVPSTC, and EPSTC. It will be recalled that other variables have been investigated for unit root before. The panel unit root test for these three variables are presented in Table 2

Table 2. ADF and IPS unit root test for compliance and VR of accounting information

\begin{tabular}{lllll}
\hline Variable & IPS statistics & Order of integration & ADF statistics & Order of integration \\
\hline TC & 9.03329 & $\mathrm{I}(1)$ & 234.390 & $\mathrm{I}(1)$ \\
\hline BVPSTC & 5.06502 & $\mathrm{I}(1)$ & 145.863 & $\mathrm{I}(1)$ \\
\hline EPSTC & 12.7762 & $\mathrm{I}(0)$ & 329.921 & $\mathrm{I}(0)$ \\
\hline
\end{tabular}

Source: Author's computation, 2020 
The panel results show that TC and BVPSTC are both integrated of order one that is I(1). This is an indication that both of them are stationary after the first difference. EPSTC is stationary at levels that are $\mathrm{I}(0)$. The result implies that all three variables are suitable to be included in the panel estimation.

\subsection{Cross-Sectional Dependence Test for Compliance With IFRS 1 and VR of Financial Information}

The application of panel data is more justified because the existence of cross-sectional dependence can render the results from the ordinary pool regression invalid. Therefore, the cross-sectional dependence test is considered and the result is presented as follows.

Table 3. Cross-sectional dependence test for compliance and value relevance of accounting information

\begin{tabular}{llll}
\hline Test & Statistic & d.f. & Prob. \\
\hline Breusch-Pagan LM & 25875.00 & 1035 & 0.0000 \\
\hline Pesaran scaled LM & 544.9560 & & 0.0000 \\
\hline Pesaran CD & 160.8571 & & 0.0000 \\
\hline
\end{tabular}

Source: Author's computation, 2020

As the previous results on the cross-sectional dependence test, pool regression will not be suitable for the analysis of the relationship between compliance and value relevance. Therefore, panel data estimation is adopted here as well.

\subsection{Panel Data Estimation for Compliance With IFRS 1 and VR of Accounting Information}

The Fixed and random effect estimation is done. The HAUSMAN test is also conducted to choose between the two. The outcome is revealed in Table 4.

Table 4. Random effect result for compliance and VR of accounting information for the combined periods 1993 to 2017.

\begin{tabular}{lllll}
\hline Variable & Coefficient & Std. Error & t-Statistic & Prob. \\
\hline C & -0.1361052 & 0.01046781 & -13.00227 & 0.0000 \\
\hline TC & 0.1841621 & 0.01261747 & 14.59580 & 0.0000 \\
\hline BVPS & -0.2001018 & 0.01231869 & -16.24376 & 0.0000 \\
\hline EPS & 0.8972562 & 0.04938600 & 18.16823 & 0.0000 \\
\hline BVPSTC & 0.2391950 & 0.01416110 & 16.89216 & 0.0000 \\
\hline EPSTC & -0.1154145 & 0.00 .625190 & -18.43958 & 0.0000 \\
\hline \multicolumn{5}{l}{ Effects Specification } \\
\hline R-squared & Weighted Statistics & S.D. & \\
\hline Adjusted R-squared & 0.880881 & & \\
\hline S.E. of regression & 0.880360 & & \\
\hline F-statistic & 912.7190 & & \\
\hline Prob(F-statistic) & 1691.968 & & \\
\hline HAUSMAN Test Probability & 0.000000 & & \\
\hline
\end{tabular}

Source: Author's computation, 2020 
The results in Table 4 explain the relationship between compliance with IFRS disclosure and the value relevance of accounting information. The Random effect results I preferred due to the probability of the HAUSMAN test which is 1.0000 .

The three variables of interest which are going to show the effect of compliance with IFRS 1 on the value relevance of accounting information are TC, BVPSTC, and EPSTC. Their coefficient in the estimated random effect model is presented as follows;

TC is the compliance with IFRS 1 and the coefficient from the random effect result is 0.1841621 and it is statistically significant at 5\%. This result implies that the higher the compliance level with IFRS 1 the more the VR of financial reports. In the same vein, the result implies that an increase in the level of compliance among the companies will significantly improve the value relevance of financial statements.

BVPSTC is the variable that indicates how the interaction between BVPS and compliance affects the VR of accounting information. The coefficient is 0.2391950 and it is statistically significant at $5 \%$. This shows that the values of BVPS as the companies comply with IFRS 1 will significantly influence their share pieces positively. In other words, BVPS becomes more value relevant as accounting information criteria when the companies comply with IFRS disclosure.

The other variable in the estimated model is EPSTC. The coefficient is -0.1154145 and also significant at $5 \%$. This implies that EPS becomes more value relevant as the firms comply more with IFRS disclosure, but the coefficient is negative, which is an indication that the interaction of EPC with compliance has an inverse relationship with the share price.

The $\mathrm{R}$ square in the estimated random effect model for compliance and VR is 0.880881 . This is an indication that about $80 \%$ of the systemic variation in share price is explained by the accounting information criteria when they comply with IFRS disclosure. This result implies that the value relevance of accounting information becomes more significant when there is an increase in the level of compliance with IFRS 1.

\subsection{Comparison of the Results on Compliance and IFRS Adoption as Its Effects on VR}

From the discussions on both the IFRS adoption and compliance with IFRS disclosure as they affect the VR of accounting information among South African companies, major differences in their results are summarised in Table 5.

Table 5. Compliance, IFRS adoption, and VR of accounting information results

\begin{tabular}{llll}
\hline Indicator & Compliance & IFRS adoption & Remark \\
\hline R square & 0.880881 & 0.634928 & $\begin{array}{l}\text { Accounting information has more VR when } \\
\text { the companies complied with IFRS 1 } \\
\text { disclosure requirements than just adoption of } \\
\text { IFRS }\end{array}$ \\
\hline BVPS & BVPSTC: 0.2391950 & BVPSIFRS: -0.484716 & $\begin{array}{l}\text { BVPS is more influenced by compliance } \\
\text { than just the adoption of IFRS. This shows } \\
\text { that it has more impact on the share price } \\
\text { (Shen companies comply with IFRS 1 } \\
\end{array}$ \\
& (Significant) & disclosure requirements. \\
\hline EPS & EPSTC: & EPSIFRS: -0.194746 & $\begin{array}{l}\text { EPS exhibit a negative and significant } \\
\text { relationship with a share price under both } \\
\text { compliance and adoption of IFRS }\end{array}$ \\
& 0.1154145 & (Significant) &
\end{tabular}

Source: Author's computation, 2020

From the comparative analysis, the initial opinion that the VR of accounting information and IFRS adoption may likely be different from VR of financial reports and compliance with IFRS disclosure is valid.

The result shows that the VR of financial reports has about $80 \%$ explanatory power when there is compliance while the explanatory power is about $63 \%$ when IFRS is adopted. The implication of this is that accounting information has more 
VR when the compliance level is high. It implies that the adoption of IFRS might not necessarily mean that companies have complied with the disclosures of IFRS. Therefore, it shows that compliance with IFRS 1 is more important than just adopting IFRS when considering the VR of accounting information.

Unlike, under the adoption of IFRS where the change in VR as a result of the EPS of the firms is mainly, both BVPS and EPS are both responsible for the change in VR of accounting information under the compliance model. The general implication of this result is that both BVPS and EPS become more important in the value relevance of accounting information when there is an increase in the level of compliance among the firms.

\section{Conclusion}

Literature showed that the standards were accepted in most of the countries but on the other hand, complying with IFRS does not mean some companies are producing value-relevant accounting information. Investors should not only focus on the increase in VR but they need to consider the EPS and the book value as well.

The study revealed that South African public companies highly complied with common standards. There is a significant positive relationship between compliance and VR of financial reports. Companies that complied with IFRS 1 enhanced the VR of the accounting system.

\section{Limitations of the Study}

The VR model that was employed to analyze the data is based on secondary data. Data was extracted from the financial reports of the listed firms, Johannesburg Stock Exchange (JSE) and McGregor BFA Library. The financial reports normally are audited by external auditors during the period of the disclosure. The reliability of the data that was extracted from McGregor BFA will rest on the preparers of the database which is a private organization.

The sample of this study is comprised of forty-six companies that are from nine different sectors operating in South Africa. The sample was limited quantitatively as far as the research data is concerned. As a result, the outcome of the study cannot be generalized across the whole of South Africa.

The common standards were formally introduced in 2005 and thereafter some of the standards were revised, changed as well as introducing new standards. The current study can hardly control all the changes that were implemented by the IASB during the period under investigation.

Lastly, the study might have not captured all the fundamental signals that are employed by several market participants.

\section{Suggestions for Future Studies}

Regulators in South Africa should make some improvements to the investment scenarios by making sure that the financial accounting information that is published by companies is compiled according to the IFRS requirements so that the investors do not make wrong decisions thereby leading to fatal consequences to the economy.

The study sample is composed of forty-six public firms from nine sectors of which future studies can increase the sample so that the findings can be generalized.

Future studies can also use primary data or mixed data for investigating the VR of financial statements.

An analysis controlling some fundamental signals such as the corporate governance mechanism, size of the audit company as well as the country's economic policies should be taken into consideration.

\section{References}

Aggreh, M., Malgwi, C., Aggreh, M. S., \& Enyi-Igbokwe, A. E. (2018). Does adoption of IFRS affect financial performance evidence from nigerian deposit money banks?. International Journal of Accounting \& Financial Reporting, 8(3). https://doi.org/10.5296/ijafr.v8i3.13309

Alade, M. E., Olweny, T., \& Olouch, O. (2017). Compliance with IFRS \& value relevance at the Nigerian stock market. International Journal of Economics Commerce.

Alali, F., \& Foote, P. S. (2012). The value relevance of IFRS: Empirical evidence in an emerging market. The International Journal of Accounting, 47(1), 85-108. https://doi.org/10.1016/j.intacc.2011.12.005

Archel, P., Hussilos, J., Larrinaga, C., \& Spence, C. (2009). Social disclosure, legitimacy theory and the role of the state. Auditing and Accountability Journal, 22(8), 1284-1307. https://doi.org/10.1108/09513570910999319

Asika, E. R. (2018). Effect of IFRS on value relevance of accounting information: evidence from quoted manufacturing firm in Nigeria. International Open Access Journal, 2(5). https://doi.org/10.31142/ijtsrd18346 
Baig, M., \& Khan, S. A. (2016). Impact of IFRS on earnings management: comparison of Pre-Post IFRS in Pakistan. $3^{\text {rd }}$ International Conference on New Challenges in Management \& Organisation. Organisation \& Leadership Dubai, 2 May, Dubai, UAE. Procedia Social \& Behavioural Sciences, 2(30), 343-350. https://doi.org/10.1016/j.sbspro.2016.09.043

Baigrie, I., \& Coetsee, D. (2016). An analysis of the financial reporting compliance of South African public agricultural companies. Journals of Economics and Financial Science, 9(3), 833-853. https://doi.org/10.4102/jef.v9i3.73

Burlea-Schiopoiu, A., \& And Popa, I. (2013). Legitimacy theory, in encyclopedia of corporate social responsibility. Springer, 1579-1584. https://doi.org/10.1007/978-3-642-28036-8_471

Cascino, S., \& Gassen, J. (2015). What drives the comparability effect of mandatory IFRS adoption?. Review of Accounting Studies, 20(1), 242-282. https://doi.org/10.1007/s11142-014-9296-5

Chan, R. S. Y., Lau, C. K. S., \& Ng, A. W. (2011). Compliance \& value relevance of audit committees: evidence from Hong Kong. Journal of Financial Reporting \& Accounting, 9(1). https://doi.org/10.1108/19852511111139813

Cooke, T. E. (1992). The impact of size, stock marketing listing, and industry type of disclosure in annual reports of Japanese listed corporations. Accounting and Business Research, 22(1992), 229-237. https://doi.org/10.1080/00014788.1992.9729440

Cormier, D., \& Magnan, M. L. (2016). The advent of IFRS in Canada: incidence of value relevance. Journal of International Accounting Research, 15(3), 113-130. https://doi.org/10.2308/jiar-51404

Deegan, C. (2002). Introducing and legitimizing of social and environmental disclosures-a theory foundation. Accounting, Auditing, and Accountability Journal, 15(3), 282-311. https://doi.org/10.1108/09513570210435852

Desoky, A., \& Mousa, G. (2014). The value relevance and predictability of ifrs accounting information: the case of gcc stock markets. International Journal of Accounting and Financial Reporting, 4(2), 215. https://doi.org/10.5296/ijafr.v4i2.6501

Edeigba, J., Gan, C., \& Amenkheinan, F. (2018). The effects of organisational culture on ifrs adoption: evidence from Nigerian companies. International Journal of Accounting and Financial Reporting, 8(1). https://doi.org/10.5296/ijafr.v8i1.12713

Huang, T., \& Pepper, M. B. (2014). Implanting a sustainability balanced scorecard to contribute to the process of organizational legitimacy assessment. Australasian Accounting, Business and Finance Journal, 8(2), 15-34. https://doi.org/10.14453/aabfj.v8i2.3

IMF Country Reports 15/57 South Africa. (2015). Financial sector assessment program detailed assessment of implementation on IOSCO objectives and principles of securities regulation. https://doi.org/10.5089/9781498390866.002

Islam, M. A., Ali, R., \& Ahmad, Z. (2011 May). Is modified jones model effective in detecting earnings management evidence from a developing economy?. International Journal of Economics and Finance, 3(2). https://doi.org/10.5539/ijef.v3n2p116

Jarvis, S. L. D. (2014). Policy transfer, neo-liberalism of coercive institutional isomorphism? Explaining the emergence of a regime for quality assurance in Hong Kong. Higher Education Sector Policy \& Society, 33(2014), 237-252. https://doi.org/10.1016/j.polsoc.2014.09.003

Jianu, L., Jianu, L., Ileanu, B., \& Herteliu, B. (2014). The value relevance of financial reporting in Romania. Retrieved from https//www.researchgate.net/publication/27684762

Kazemian, S., \& Sanusi, M. Z. (2015). Earnings management and ownership structure. International Accounting \& Business Conference 2015 /ABC 2015. Procedia Economics and Finance, 31(2015), 618-624. https://doi.org/10.1016/S2212-5671(15)01149-1

Khanna, M. (2014). Value relevance of accounting information: an empirical study of selected Indian firms. International Journal Scientific and Research Publications, 4, 1-6.

Lin, S. (2012). The determinants and consequences of heterogeneous IFRS compliance levels following mandatory IFRS adoption: evidence from a developing country. Journal of International Accounting Research, American Accounting Association, 11(1), 113-118. https://doi.org/10.2308/jiar-10226 
Mahmud, T. (2019). Legitimacy theory and its relationship to CRS disclosure (A Literature Review). The Keizai Ronkyuno, 163(2019).

Mousa, G., \& Hassan, N. (2015). Legitimacy theory and environmental practices: short notes. International Journal of Business and Statistical Analysis, 2(1). https://doi.org/10.12785/ijbsa/020104

Msuya, R., \& Maleko, G. (2015). N-n-compliance and challenges of implementing IFRS in savings and credits cooperative societies (SACCOS) in Shinyanga Region - Tanzania. Journal of Business Administration and Education, 7(1), 17-33.

Muller, O. V. (2014). The impact of IFRS adoption on the quality of consolidated financial reporting. Procedia -Social \& Behavioural Sciences, 109(2014), 976-982. https://doi.org/10.1016/j.sbspro.2013.12.574

Nwaobia, A. N., Ogundajo, G. O., \& Kwarbai, J. D. (2016). Value relevance of accounting information and firm value: a study of consumer goods manufacturing sector in Nigeria. European Journal of Business and Management, 8(24).

Odoemelam, N., Okafor, R. G., \& Ofoegbu, N. G. (2019). Effect of International Financial Reporting Standard (IFRS) adoption on earnings value relevance of quoted Nigerian firms. Accounting, Corporate Governance \& Business Ethics: Cogent Business \& Management, 6, 1643520. https://doi.org/10.1080/23311975.2019.1643520

Okafor, T. G., Oguebi, A., \& Anene, N. (2017). IFRS adoption and value relevance of accounting information in Nigeria: an empirical study. Journal of Modern Accounting and Auditing, 13(10), 421-434. https://doi.org/10.17265/1548-6583/2017.10.001

Palea, V. (2013). IAS/IFRS and financial reporting quality lessons from a European experience. China Journal of Accounting Research, 6(2013), 247-263. https://doi.org/10.1016/j.cjar.2013.08.003

Panda, B., \& Leepsa, M. N. (2017). Agency theory: review of theory and evidence on problems and perspective. Indian Journal of Corporate Governance, 10(1), 74-95. https://doi.org/10.1177/0974686217701467

Phan, D. H. T., \& Mascitella, B. (2014). Potential adoption of International Financial Reporting Standards (IFRS) in Vietnam: from legitimacy to isomorphism. Conference Proceedings, The Twenty-Six Asian-Pacific Conference on International Accounting Issues, 26-31 October 2014, Taipei, Taiwan.

Pududu, M. L., \& De Villiers, C. (2016). Earnings management through loss avoidance: does South Africa have a good story to tell?. SAJEMS NS, 19(1), 18-34. https://doi.org/10.4102/sajems.v19i1.1124

Quezzani, M. R., \& Alami, Y. (2014). The compliance of methods of implementation of IFRS: study of an impact of a relevance of accounting information. Asian Journal of Finance and Accounting, 6(2). https://doi.org/10.5296/ajfa.v6i2.5884

Ross, S. (1973). The economy theory of agency, the principal's problem. American Economic Review, 63, 134-139.

Saidu, S., \& Dauda, U. (2014). An assessment of compliance with IFRS framework at first time adoption by the quoted banks in Nigeria. Journal of Finance and Accounting, 2(3), 64-73.

Santos, E. S., Da Silva, M., Almeida, F., Sheng, H. H., \& Lora, M. I. (2018). Compliance with IFRS disclosure and analysts forecast errors: evidence from Brazil. Revista Cantabilidade Vista and Revista, Universidade Federal de Minas Gerais, Belo Horizonte, 29, 77-100. https://doi.org/10.22561/cvr.v29i1.3906

Sari, P., \& Prihandini, W. (2019). Corporate social responsibility and tax aggressiveness in perspective legitimacy theory. International Journal of Economics, Business and Accounting Research (IJEBAR). International Journal, 3(4). https://doi.org/10.29040/ijebar.v3i04.726

Suchman, M. (1995). Managing legitimacy, strategic and institutional approaches. Academy of Management Review, 21(3), 571610. https://doi.org/10.2307/258788

Swait, N., Patel, A., \& Maroun, W. (2018). Exploring the decision to adopt IFRS early. Economic \& Financial Sciences, 11(1). https://doi.org/10.4102/jef.v11i1.171

Umoren, O. A., \& Enang, E. R. (2015). IFRS adoption and value relevance of financial statements of Nigerian listed banks. International Journal of Finance and Accounting, 4(1), 1-7.

Usman, A. B., \& Ndagi, S. (2019). Does compliance with accounting standards disclosure requirements matter on a value relevance of other comprehensive income items in Nigeria. 
Uthman, A. B., \& Abdul-Baki, Z. (2014). The value relevance of accounting information in Nigeria: Analysts perception in A IFRS regime. Journal of Accounting \& Management (JAM), 4(1).

Uyar, A., Kilic, M., \& Ataman, B. (2016). The level of compliance with IFRS influences the value of accounting information. Economic Research, 19(1), 148-161. https://doi.org/10.1080/1331677X.2016.1163949

Vasek, M. D. L. (2015). Are IFRS really global standards of financial reporting? Analysis of worldwide jurisdiction profiles. 16th Annual Conference on Finance and Accounting ACFA Prague 29 ${ }^{\text {th }}$ May 2015. Procedia Economics \& Finance, 25(2015), 156-165. https://doi.org/10.1016/S2212-5671(15)00724-8

Yasas, T. G., \& Perera, H. A. P. L. (2019). The impact of IFRS adoption on quality of accounting information: evidence in Sri Lanka. Kelaniya Journal of Management, 8(1). https://doi.org/10.4038/kjm.v8i1.7566

Zehri, F., \& Chouaibi, J. (2013). Adoption determinants of the IAS/IFRS by developing countries. Journal of Economics, Finance and Administrative Science, 18(2013), 56-62.

Zicke, J., \& Kiy, F. (2017). The effect of accounting standards on the financial reporting properties of private firms: modernization act. Business Research, 10, 215-248. https://doi.org/10.1007/s40685-017-0051-1

Zwan, P., \& Merwe, N. (2013). The message conveyed by IFRS-Compliant information, A South African perspective. International Business and Economics Research Journal Sept 2013, 12(9). https://doi.org/10.19030/iber.v12i9.8051

Zyznarska-Dworczak, B. (2018). Legitimacy theory in management accounting research. Problem Zarzadzania, 16(1). https://doi.org/10.7172/1644-9584.72.12

\section{Appendix}

Content analyses score chart

\section{DISCLOSURE REQUIREMENTS}

\section{ONE ZERO TOTAL}

1. Disclose the Statement of financial position

2. Disclose the Statement of comprehensive income

3. Disclose the Statement of other comprehensive income

4. Disclose the Statement of changes in equity

5. Disclose the Statement of cash flow

6. Disclose the Notes and preceding year comparative information

7. Disclose the name of reporting entity as well as the date of the reporting period

8. Disclose the presentation currency (rand only)

9. Disclose the statement of compliance with IFRS

10. Disclose reported period for instance one year or six months.

11. Disclose the basis of the preparation of financial reports and the accounting policies applied.

12. Disclose the present earnings per share (EPS) for the income statement presented.

13. Depreciation method of PPE

14. Disclose the useful lives of the assets including the depreciation rates applied.

15. Disclose the investment property, whether fair value model /cost model.

16. Disclose the treatment of research costs as well as the basis for capitalization of development costs.

17. Disclose the basis on which income and expenses arising from financial 
assets and financial liabilities are recognized and measured.

18. Disclose the criteria applied for impairing and writing off financial assets.

19. Disclosure on leases

20. Disclosure on inventories

21. Disclosure on provisions

22. Disclosure on share-based payments,

23. Disclosure on taxes including deferred taxes

24. Disclosure on revenue recognition

25. Disclosure on government grants etc.

26. Disclose the title of the standard as well as the interpretation.

27. Disclose the change of accounting policy including any amendments.

28. Disclose the profit or loss for non-controlling interests

29. Disclose the revenue and finance cost for associates.

30. Disclose revenue rising from the sale of goods

31. Disclose the total number of shares issued and fully paid

32. Disclose the total number of shares that were issued but not fully paid.

33. Disclose the total number of dividends proposed or declared and authorized before the financial reports but not recognized to the ordinary shareholders during the period.

34. Disclose the amount of liabilities for current tax, deferred tax liability.

35. Disclose the amount of assets for deferred tax assets and also for non-controlling interests.

36. Disclose the amount of issued capital and reserves attributable to ordinary shareholders.

37. Disclose the value of income from continuing operations as well as from discontinued operations attributable to ordinary shareholders.

38. Disclose the carrying amount of inventories whether it is carried at fair value minus all costs to sell.

39. Disclose receivables according to their classes for instance trade receivables, receivables from subsidiaries or other receivables depending on the operation of the entity.

40. Disclose the deferred tax assets as well as deferred tax liabilities separately in the balance sheet.

41. Classification of deferred tax assets in the following categories; non-current assets or current assets.

42. Disclose payables according to their classes for instance payables to subsidiaries or payables to related parties, accruals depending on the operation of the firm.

43. Present the cash flow according to the following three activities; operating, investing, and financing activities.

44. Disclose the cash flows obtained from taxes on income;

45. Taxes paid should be disclosed as cash flows from operating activities unless specifically identified with financing and investing activities. 
For cash flows, disclose;

46. Interest received for the period

47. Interest paid for the period

48. Dividends received for the period

49. Dividends paid for the period

50. Disclose of cash and cash equivalents.

51. Disclose reconciliations of amounts in cash flow statements with cash and cash equivalents in the balance sheet.

52. Disclose either on the face of the balance sheet or in the notes the carrying amounts of loans and receivables.

53. Disclose either on the face of the balance sheet or in the notes the carrying amounts of available-for-sale financial assets.

54. Disclose the value for the current basic and diluted EPS of the company, even if the value is either positive or negative (a loss per share should be disclosed).

55. Disclose the value of government grants recognized.

56. Disclose the borrowings according to the following classes; current and non-current portion

Source: Author's computation, 2020

\section{Copyrights}

Copyright for this article is retained by the author(s), with first publication rights granted to the journal.

This is an open-access article distributed under the terms and conditions of the Creative Commons Attribution license (http://creativecommons.org/licenses/by/4.0/). 